GA-C19462

Rev. 1

\title{
UPDATED \\ DIII-D EXPERIMENTAL PLAN \\ FOR FY-1989
}

\author{
by \\ FUSION DIVISION STAFF \\ J.L. LUXON, EDITOR
}

GENERAL ATOMICS PROJECT 3466

AUGUST 1989

\author{
Prepared under \\ Contract No. DE-AC03-89ER51114 \\ for the San Francisco Operations Office \\ U.S. Department of Energy
}

\author{
AUGUST 1989
}




\section{DISCLAIMER}

This report was prepared as an account of work sponsored by an agency of the United States Government. Neither the United States Government nor any agency thereof, nor any of their employees, makes any warranty, express or implied, or assumes any legal liability or responsibility for the accuracy, completeness, or usefulness of any information, apparatus, product, or process disclosed, or represents that its use would not infringe privately owned rights. Reference herein to any specific commercial product, process, or service by trade name, trademark, manufacturer, or otherwise, does not necessarily constitute or imply its endorsement, recommendation, or favoring by the United States Government or any agency thereof. The views and opinions of authors expressed herein do not necessarily state or reflect those of the United States Government or any agency thereof. 


\section{APPROVALS}
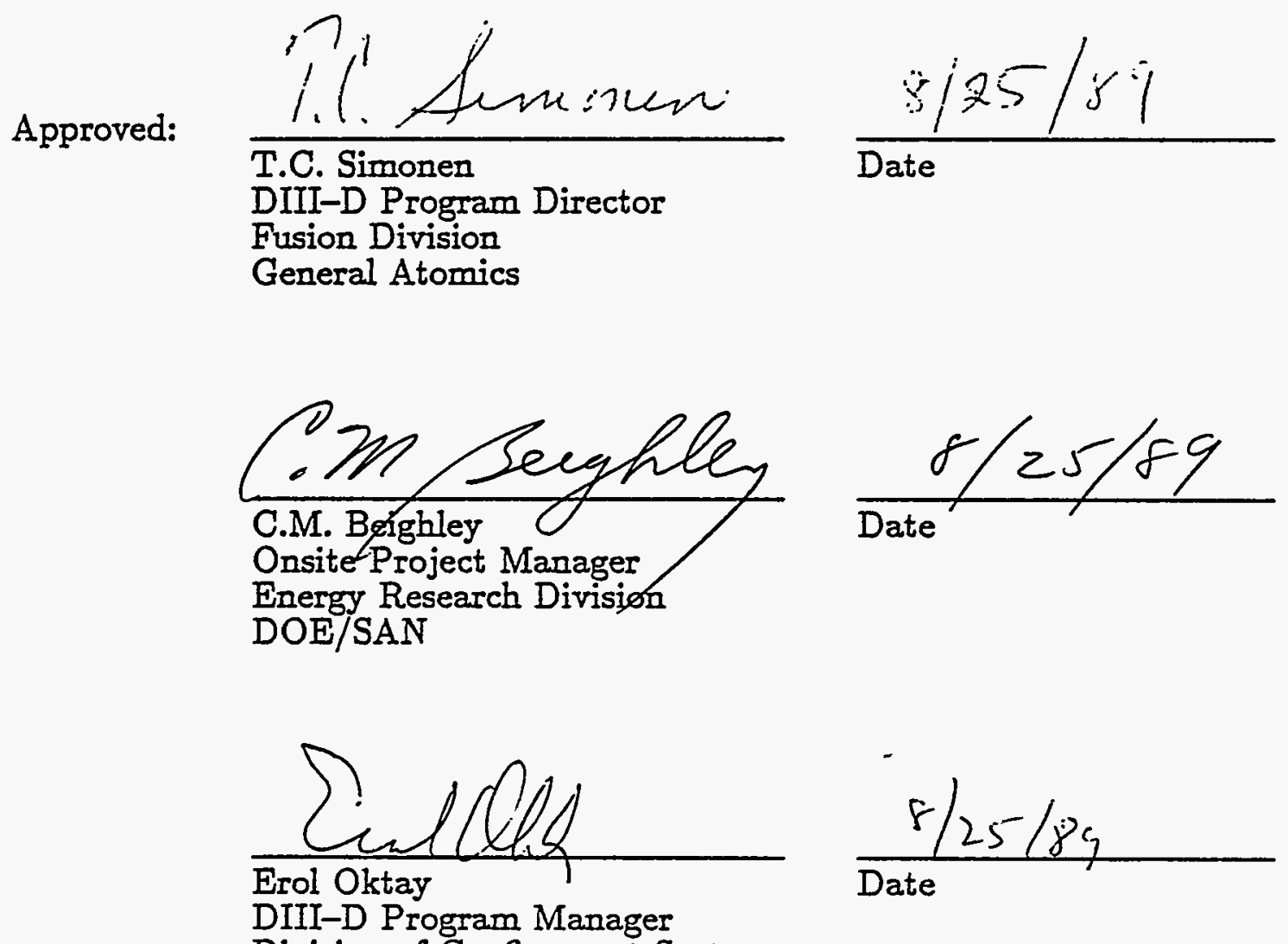

DIII-D Program Manager

Division of Confinement Systems DOE/ER-55 


\section{FOREWORD}

This document presents the planned experimental activities for the DIII-D tokamak facility for the period FY89. This experimental plan is a revision of the plan issued in November 1988 and reflects the enhanced DIII-D response to the Transport Initiative called for by DOE given in Section 8. This new effort includes diagnostic improvements and enhancements, increased operating time and data analysis, implementation of the Advanced Divertor Program, and implementation of the pellet injector. In order to clearly communicate the changes, the changes will be presented largely as additions to the text in bold-faced type.

This plan is part of a five year contract between General Atomics and the Department of Energy. The plan will be reviewed by both organizations and approved by the DIII-D Program Director, Fusion Division, General Atomics, the Onsite Project Manager, SAN Office, DOE, and the DIII-D Program Manager, Division of Confinement Systems, Washington, D.C. It is anticipated that this document will be updated yearly, and that the progress of the DIII-D program will be reviewed quarterly against this plan. In the event of major budgetary, technical, or programmatic changes this document will be revised. 


\section{LIST OF ACRONYMS}

APS

$a$

B

CIT

DIII-D

ECH

ELM

FY

H-mode

I

IAEA

IBW

IBW

ITER

ITG

JET

L-H Transition

L-mode
American Physical Society

Minor radius of plasma

Magnetic field

Compact Ignition Tokamak

Tokamak Fusion Device located at General Atomics

Electron Cyclotron Heating

Edge localized mode that limits energy storage in plasma

Fiscal year

A high regime of tokamak confinement

Plasma current

International Atomic Energy Agency

Ion Bernstein Wave method of ion cyclotron heating

Ion Cyclotron Heating

International Thermonuclear Experimental Reactor

Ion Temperature Gradient

Joint European Tokamak located in England

Transition from L-mode to $\mathrm{H}$-mode

A low regime of tokamak confinement 
OFE Office of Fusion Energy

O-mode A mode of microwave propagation in which the microwave electric field is parallel to the toroidal magnetic field

Tokamak safety factor $q=3$ means that a magnetic field line traverses the toroidal direction three times in one poloidal rotation.

R\&D Research and development

If Radio frequency

$\mathrm{X}$-mode A mode of microwave propagation in which the microwave electric field is perpendicular to the toroidal magnetic field

$\mathrm{X}$-point The location where the magnetic field is purely toroidal (no poloidal component)

The ratio of plasma pressure to magnetic field pressure.

$\Omega_{\mathrm{H}} \quad$ Hydrogen ion cyclotron frequency

$\beta_{\mathbf{p}} \quad$ Beta Poloidal 


\section{CONTENTS}

APPROVALS ........................... iii

FOREWORD .................... iv LIST OF ACRONYMS . . . . . . . . . . . . . . . . v

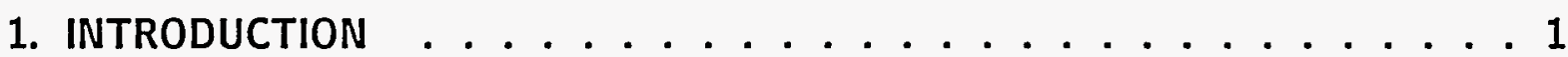

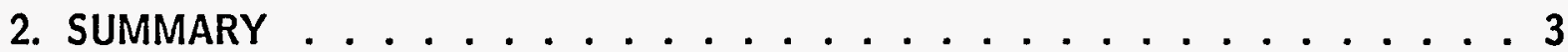

3. EXPERIMENTAL PLAN . . . . . . . . . . . . . . . . 10

4. GOALS FOR EXPERIMENTS IN $1989 \ldots \ldots$

5. DETAILED RESEARCH PLAN . . . . . . . . . . . . . 16

6. DETAIL HARDWARE PLAN . . . . . . . . . . . . . . 20

7. MILESTONE SCHEDULE (Research Operations) . . . . . . . . . . 23

8. DIII-D CONFINEMENT UNDERSTANDING PROGRAM . . . . . . . . . 25

9. DIII-D PROGRAM TO SUPPORT ITER AND CIT . . . . . . . . . . . . 30 Appendix TECHNICAL DIRECTION TO INCREASE TRANSPORT EMPHASIS 34 


\section{INTRODUCTION}

This document reports the revision of the 1989 Experimental Plan for the period of July to December 1989. This revision is made because of substantial redirection by DOE in response to the transport initiative and the needs of CIT and ITER. Additional experimental time was also funded to help meet those needs. The DIII-D program that results continues to pursue our long-range goals as put forth in the 5-year plan although realization of the ultimate goals is going to take somewhat longer.

The long-range DIII-D $5 \mathrm{yr}$ plan is directed ultimately at the goal of achieving good confinement at high beta in a plasma with non-inductively driven current. This is important to the design of a steady-state reactor. This program may be thought of as occurring in two phases. In the first phase of the program we are separately investigating high beta plasma confinement in inductively-driven plasmas, and noninductive current drive. In the second phase we will combine these two elements to investigate high beta plasma confinement with non-inductive current drive.

The FY89 plan continues the first phase of the DIII-D experimental effort that contains a strong focus on beta and confinement in non-circular plasma configurations and in the divertor configuration in particular. Important work also continues in the development of if heating systems for heating, profile control, and current drive. This research is coupled to theoretical efforts at General Atomics.

The FY89 research program outlined herein is diverse and multifaceted. However, it is also characterized by a greater synthesis of techniques toward a common goal. An example is the application of $\mathrm{ECH}$ for sawtooth suppression that would improve the low $q$ confinement and allow higher $\beta$ to be obtained. We believe this research program will provide a solid foundation for the continued development of the tokamak toward high beta steady-state reactor application.

The DIII-D FY89 research program will provide results that will help resolve many CIT and ITER Physics R\&D issues. In addition, DIII-D confinement studies will be an important input to the newly formed National Transport Task Force. 
The outline for the remainder of this plan is as follows:

Sec. 2. Summary discussion of the Experimental Plan.

3. A bar chart which summarizes the proposed Experimental Plan.

4. A summary of the research goals for FY89.

5. A tentative detail breakdown of the research plan.

6. A detail plan for major hardware tasks. 


\section{SUMMARY}

The program proposed here is designed to support and build toward the longterm plan put forward during 1987 for the DIII-D facility. This plan has as its ultimate goal developing sufficient understanding and predictive capability to enable the demonstration of a high beta plasma with non-inductively driven toroidal current. The early stages of this plan call for the optimization of the plasma configuration for good confinement at high beta while simultaneously developing the needed if power systems for current drive, profile control, and heating. The long-range research plan

is given in Table I and in more detail in Table II together with a schedule of associated proposed milestones.

The research plan for FY89 is broken down into five subject areas: high beta, confinement, boundary physics, If heating, and current drive. The goals of experiments in each of these areas are listed and simply stated in Section 4. Here we provide a more detailed discussion of these research plan elements.

\section{High Beta Research}

High beta studies have shown stable long-pulse high $\beta$ operation up to $\beta_{\mathrm{T}}=$ $7.4 \%$ in single-null and $8 \%$ in double-null divertor plasmas. The beta limit scaling from Doublet III, $\beta_{\mathrm{T}}(\%)=3.5 \mathrm{I} / \mathrm{aB}(\mathrm{MA} / \mathrm{m} / \mathrm{T})$, has been shown to hold in DIII-D. Considerable progress has been made, via detailed observations and theory calculations, on identifying the cause of the first regime beta limit. A sequence of essentially pressure-driven, resistive, global modes with toroidal mode number $n=4,3,2,1$ appear as the beta limit is approached. Ultimately, the highest $\beta_{\mathrm{N}}=\beta_{\mathrm{T}} /(\mathrm{I} / \mathrm{aB})$ is limited by a fast growing $n=1$ mode which looks like an external kink.

Fiscal year 1989 efforts along this line will be in the area of detailed transport studies at the beta limit. This effort will include studying possible fast ion transport and fluctuation data from the UCLA scattering system. The first regime $\beta$ limit studies will be extended to more advanced plasma shapes. This work will require substantial preparatory work on the plasma shape control system. Fiscal year 1989 
Table I

INTEGRATED LONG-RANGE DIII-D PROGRAM PLAN

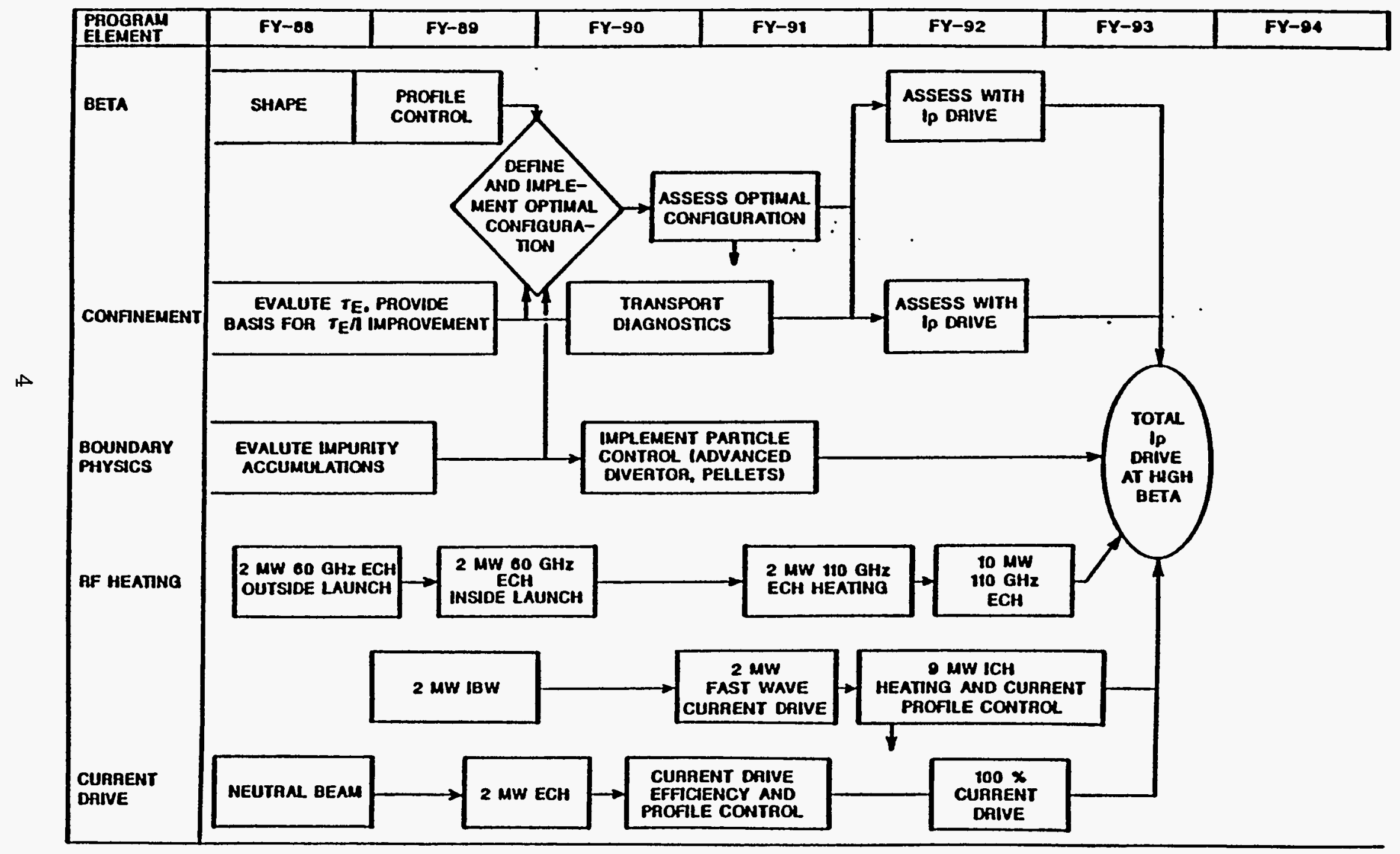


TABLE II

DIII-D LONG RANGE RESEARCH PLAN

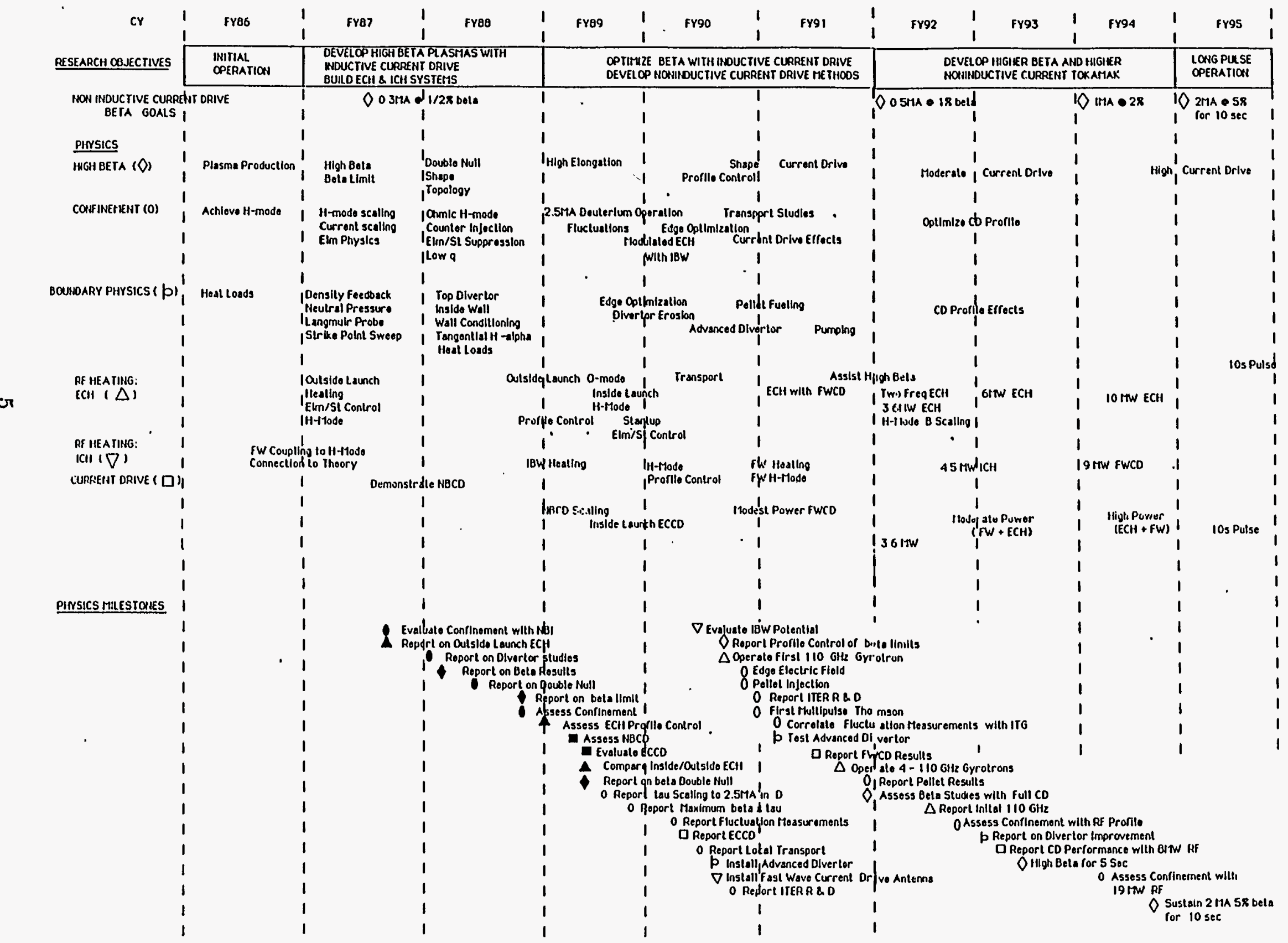


will also contain initial efforts at affecting $\beta$ limits using profile control from ECH or IBW. We also intend to try to reach higher numerical values of $\beta_{\mathrm{T}}$ by pushing up to the $\beta$ limit in the regime $q<3$. At present, the achieved $\beta$ in this regime has been limited by the energy confinement time becoming independent of $\mathrm{I}_{\mathrm{p}}$ for $q<3$. Consequently, the research topics on sawtooth suppression and ELM suppression appear variously under the beta, confinement, and If program headings. The effort to attain higher $\beta_{\mathrm{T}}$ will also be helped by the neutron shielding which will enable deuterium neutral beam injection into deuterium plasmas which yields higher beam power and better plasma confinement. These advantages may be crucial to achieving high beta in some of the more advanced limiter plasma shapes where $\mathrm{H}$-mode is probably not available. In FY89, we also intend to mount an experiment aimed at pushing into the second stable regime.

\section{Confinement Research}

The confinement research program in FY89 has components that relate to the beta program, to producing scaling information for future machine design, and to providing basic understanding in several areas of plasma transport research. $\mathrm{H}$-mode studies will continue to be emphasized. The neutron shielding will allow us to obtain the clear scaling information with deuterium neutral beam injection into deuterium plasmas, uncomplicated by isotope effects. These data will also be our contribution to a joint effort with JET to extract the size scaling of $\mathrm{H}$-mode from direct comparisons of corresponding discharges in our two machines. Following up our first production of $\mathrm{H}$-mode with $\mathrm{ECH}$ alone and even with ohmic power alone, we will continue exploring rf produced H-mode with ECH and IBW.

In more basic studies, we will seek a greater depth of understanding of interior plasma transport coefficients and processes using pulse modulation techniques and the UCLA scattering system. Because of our excellent rotation speed profile measurements derived from the charge exchange recombination diagnostic system, momentum confinement studies will come along as a by-product of scaling studies. 


\section{Boundary Physics}

Boundary physics studies in FY89 will concentrate on H-mode topics and other divertor issues relevant to future machine design efforts. We perceive that the demonstration of long pulse, steady $\mathrm{H}$-mode is a critical issue in future machine designs. We have already obtained a 5 second steady $\mathrm{H}$-mode with good confinement characterized by grassy ELMs. We have also seen effective prevention of central impurity accumulation by ELMs in high current operation. These lines of research on long-pulse and impurity control will be continued. We will also study particle transport. An effort is underway to form a collaborative arrangement with other edge plasma specialists to provide the necessary studies of erosion/redeposition, main plasma exhaust, pumping and recycling, and helium exhaust. In this area, we note the critical role that the development of helium glow wall conditioning has played in our program this year. Work will continue on defining effective methods of divertor plasma-wall interaction for future machine designs. In FY87 and early 88, our detailed investigation of ELMs in $\mathrm{H}$-mode led us to propose that ELMs are triggered by edge ballooning instabilities. In FY89, we will concentrate on the physics of the $\mathrm{L}-\mathrm{H}$ transition, bringing to bear data from the UCLA scattering system and microwave reflectometer system.

\section{Radiofrequency Heating}

The rf heating program will have two operational components in FY89: electron cyclotron heating (ECH) and ion Bernstein wave heating (IBW). The ECH program in FY87 and 88 utilized second harmonic outside launch and studied heating, obtained H-mode, suppressed sawteeth, and suppressed ELMs. Because of the low cutoff density for the available outside launch $\mathrm{X}$-mode waves, $\bar{n}_{\mathrm{e}} \lesssim 2 \times 10^{13} \mathrm{~cm}^{-3}$, this impressive list of accomplishments was performed in a density regime somewhat disjoint from other experiments, especially the high beta work which is usually done at higher density. Because of our desire to use ECH for sawtooth and ELM suppression to improve confinement at low $q$ in the beta program, we have installed both an X-mode inside launch ECH system for which the cutoff density is about $7 \times 10^{13} \mathrm{~cm}^{-3}$ and an $\mathrm{O}$-mode outside launch system for which the cutoff density is $\$ 3 \times 10^{13} \mathrm{~cm}^{-3}$. Initial experiments with the inside launch system resulted in some damaged waveguides which have been corrected and experiments are underway. The outside launch system was operational in early FY89. 
The IBW research program will begin in FY89. The entire antenna and $2 \mathrm{MW}$ generator system is installed and operational. We already know that IBW coupling to $\mathrm{H}$-mode plasmas is less sensitive to edge conditions than fast wave coupling. Initial experiments are concentrating on basic IBW heating mechanisms. Key physics issues are linear versus non-linear absorption mechanisms and majority versus minority heating schemes. By employing the tunability of the system, varying the toroidal field, and using different harmonic resonances, great flexibility in heating location can be obtained. In particular, the IBW should be useful in pressure profile control in low $\mathrm{B}_{\mathrm{T}}$, high beta plasmas. This application takes on added importance since we believe the modes which prevent the attainment of the highest value of $\beta_{\mathrm{N}}$ are primarily pressure driven.

\section{Current Drive Research}

The current drive program in FY89 will continue to investigate neutral beam (NBI) current drive and a preliminary assessment of ECH current drive. Initial NBI current drive experiments have, in addition to driving substantial currents, shown that the second stability regime can be approached. This occurs by virtue of the relatively high plasma energy developed at modest current resulting in high $\beta_{\mathrm{P}}$. Further experiments are planned to explore the second stable regime behavior. The ability of ECH to assist NBI current drive by increasing the electron temperature will be studied. Current drive using $\mathrm{ECH}$ alone may require re-orienting either the inside or outside launchers. This change requires hardware modifications and a vent, and it is currently being considered.

The revised plan presented here reflects particularly the increased emphasis on transport within both confinement and boundary physics research areas. These efforts include experiments to understand confinement, including fluctuation studies, detailed comparison of regimes with different confinement, detailed measurement of transport and development of functional dependencies; experiments to identify new confinement regimes, built upon combining the features of known regimes of enhanced confinement, and specific tests of existing theories. The completion of the shield wall allows extensive operation in deuterium which allows this work to be carried out largely with the more relevant deuterium isotope and, because of the enhanced confinement of deuterium the experiments can be carried out in more meaningful 
regimes. The revised plan also specifically addresses the identified needs of CIT and ITER. The planned responses in these areas are summarized in Section 9. Immediate responses include operation issues, performance limits, confinement understanding and physics and technology of the plasma boundary. 


\section{EXPERIMENTAL PLAN}

Table III summarizes the basic program elements for FY89. The updated plan consists of 26 weeks of operation rather than 22 weeks as in the earlier plan. Two machine vents in December and April were for ECH waveguide modifications, diagnostic improvements, and general maintenance. The updated plan strengthens the DIII-D transport program. This plan is responsive to CIT and ITER physics R\&D needs. High beta work on plasma elongation and advanced shape were delayed. 
TABLE III

UPDATED DIII-D FY89 RESEARCH PLAN (8/1/89)

BIPBRIQIEIS

ROI DATS

แESHIIGS

TOROS IEUIS \& SHUTEORHS BARDYARE ATAILABILIII

SHIBLDIIG

SCE, OOTSIDE LAOSCI O-LODS

BCE, ILSIDI LAOICI I-8ODI

IBR SIstu

OPIRATIOI ISSOBS

SHAPI COITROL

HI6H CVRPEII DXILOPखIII

POLS! LEGTH BIIISIOI

BIGB BBTL STODIIS

DOOBLS-SOLL DIInTOP

PUASU SLIPB

IRAISPOPT STODI

IBM PROSIU COSTROL

ICH ILI STPPPISSIOI

stroIn SruRILIT

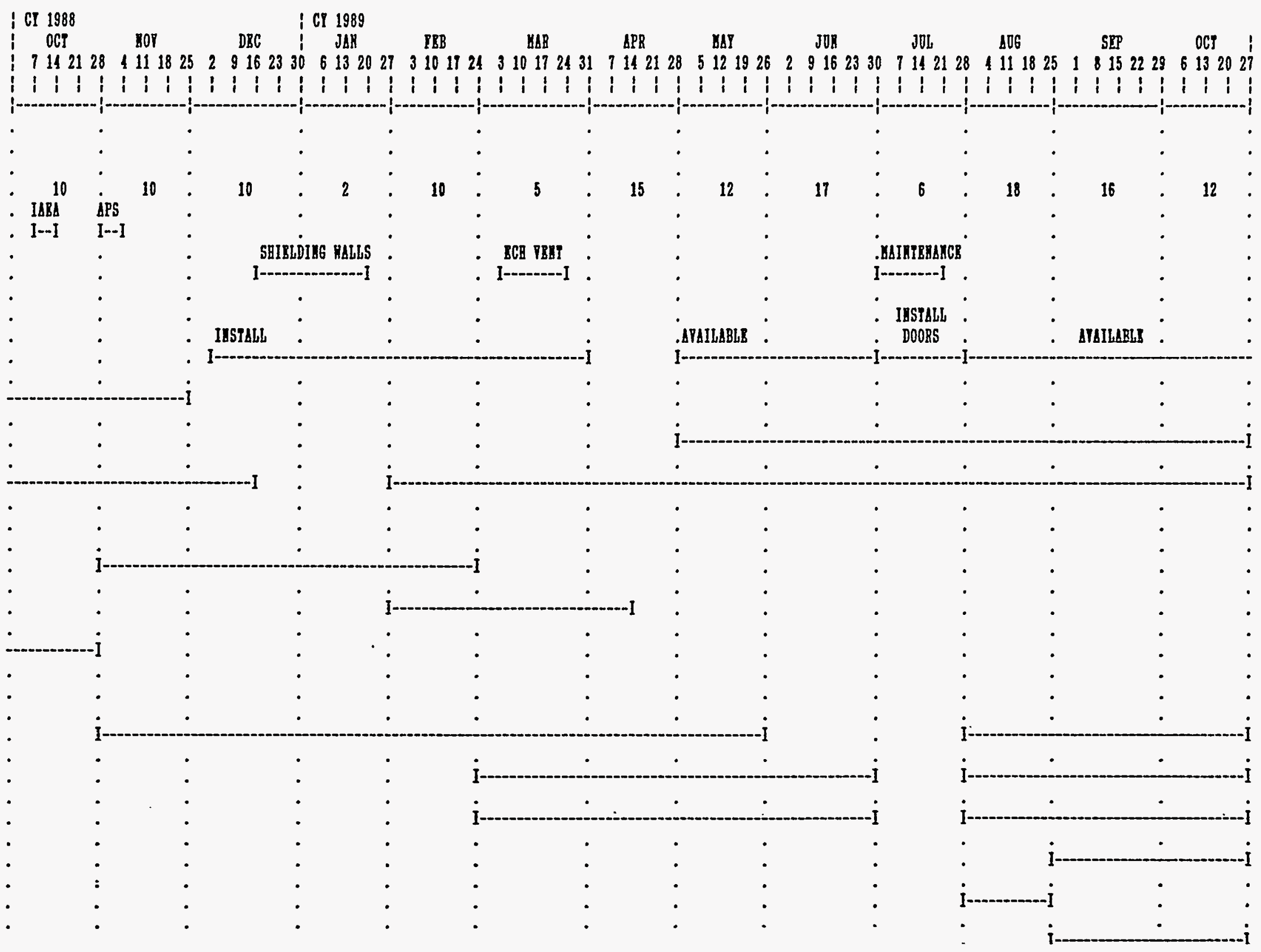




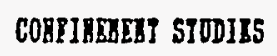

TRATSPORT STUDISS

rLDCtDLIIOS STODIIS

SCALIEG STODIrs

SIbB SCLLIIG OI I-KODB (JB?)

B-8008 MIII II

STaBILIUHIOI Of IISTaBILIYIIS roDOLATE IRAsSPOR

BODRDARI PHISICS STODISS

LORG POLSS I-BODI

PARIICLI AUD IUPWIII TRASPORT

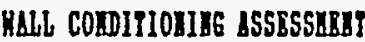

\section{BR HBLIIIG (BSSIC)}

ICA, ODTSIDE LADICB O-LODS

BCB, IASIDS USDICB I-BODI

IBH STODIBS (BLSIC)

CORREII DRIIE STODIIS

TABLE III

UPDATED DIII-D FY89 RESEARCH PLAN (8/1/89) 


\section{GOALS FOR EXPERIMENTS IN 1989}

This section contains a short summary of the principal goals for the experiments on DIII-D during 1989. The work is broken down into five subject areas: beta studies, confinement (and Transport) investigations, boundary physics, if heating program, current drive studies and CIT/ITER Physics R\&D. Each of these areas supports the others; accordingly, in some cases, you will find the same goal listed under two topics. The aim of most DIII-D experiments is to integrate these individual topics. A common example is confinement studies carried out at high beta with divertor discharges.

These goals have been modified in July as is shown in bold.

\subsection{BETA STUDIES}

The main goals in the high beta area are:

1. Develop effective control methods for more advanced plasma shapes including
a. Double-null divertors [completed].
b. Plasmas with elongation up to 2.5 .
c. Plasmas with high triangularity and indentation [delayed].

2. Extend the beta limit studies to these more advanced plasma shapes [delayed].

3. Reach the $\beta$ limit in the regime $q<3$.

4. Explore the utility of profile control derived from ECH or IBW for increasing stability [delayed].

5. Continue second stability investigations in high poloidal beta plasmas [limited effort].

6. Study plasma transport, including fast ion transport, at high beta. 


\subsection{CONFINEMENT (AND TRANSPORT) INVESTIGATIONS}

1. Evaluate confinement with deuterium injection into deuterium plasmas up to plasma currents of at least $2.5 \mathrm{MA}$.

2. Study $\mathrm{H}$-mode produced with of power alone (ECH and/or IBW).

3. Improve confinement at low $q$ by stabilizing sawteeth and/or ELMs.

4. Provide information on the size scaling of $\mathrm{H}$-mode (jointly with JET).

5. Perform a detailed transport study using pulse modulation techniques and scattering diagnostics.

6. Evaluate momentum confinement as a function of plasma parameters.

7. Conduct detailed confinement studies fluctuation diagnostics (e.g., current).

8. Continue enhanced confinement mode development and understanding.

9. Determine functional transport coefficient dependence including isotopes.

10. Improve and enhance transport diagnostics for profile and fluctuation measurements.

11. Initiate pellet injector to control density and radial gradient to improve transport studies.

\subsection{BOUNDARY PHYSICS STUDIES}

1. Demonstrate long pulse ( $\sim 5 \mathrm{sec})$ quasi-stationary $\mathrm{H}$-mode plasmas. Evaluate impurity transport properties.

2. Determine particle transport in $\mathrm{H}$-mode to understand the flat to hollow density profiles and steep edge gradients.

3. Develop an understanding of the physics of the $\mathrm{L}-\dot{H}$ transition. Identify the nature of the turbulence and fluctuations that correlate with $\mathrm{L}-$ versus $\mathrm{H}$-mode.

4. Document divertor region heat loads, particle loads, and impurity effects as a function of $\mathrm{X}$-point position and for single- and double-null divertors.

5. Continue to develop improved methods of wall conditioning.

6. Develop advanced divertor design to provide control and measurements for transport studies. 


\subsection{RF HEATING PROGRAM}

Both electron cyclotron heating (ECH) and ion Bernstein wave heating (IBW) will be studied.

\subsubsection{ECH Program}

1. Verify ECH fundamental mode heating physics.

2. Attempt to produce and study $\mathrm{H}$-mode with $\mathrm{ECH}$ alone.

3. Enhance $\mathrm{H}$-mode by means of central ECH to peak up profiles or edge $\mathrm{ECH}$ for ELM stabilization [limited].

4. Stabilize sawteeth.

5. Assist $\mathrm{NBI}$ current drive [delayed].

6. Provide a preliminary test of ECH current drive.

\subsubsection{IBW Program}

1. Explore and document IBW heating efficiency and coupling in various regimes. Key issues are linear versus non-linear heating mechanisms and majority versus minority species heating regimes.

2. Attempt to produce $\mathrm{H}$-mode with IBW alone or in combination with ECH [delayed].

3. Utilize IBW for pressure profile control in the high beta studies [delayed].

\subsection{CURRENT DRIVE STUDIES}

1. Assess (preliminary) ECH current drive.

2. Assist NBI current drive with ECH [delayed].

3. Investigate second stability behavior in current drive plasmas [limited].

\subsection{CIT/ITER PHYSICS R\&D}

1. Integrate results of above research into CIT/ITER physics programs. 
2. Develop theoretical models of plasma disruptions and compare with DIII-D data.

3. Conduct experiments to evaluate possible low voltage plasma startup. 


\section{DETAIL RESEARCH PLAN}

Table IV(a) on the following page gives the original Experimental Plan by experimental task. That schedule called for two weeks of operation followed by two non-operating weeks for a total of 22 weeks. The schedule gives the allotted time in days for the month noted.

Table IV(b) presents the revised and extended plan for the remainder of the year, based on 26 weeks operation.

The plan for the remainder of 1989 is summarized Table IV(b). Unfortunately the individual entries differ substantially from the earlier 1989 Experimental Plan [see Table IV(a)] because of specific items planned in response to the increased emphasis on transport and the needs of CIT and ITER, as well as more detailed understanding of the needs within the program elements.

The major change in emphasis is the increased emphasis on transport under both the confinement and boundary physics headings and refocusing in other areas to meet program needs. The if programs emphasis for both IBW and ECH is directed at the physics understanding of these systems. The beta work will concentrate on the role of plasma elongation which was delayed from earlier in the year due to emphasis on transport studies. The added transport tasks are supported by the four additional weeks of running time that has been provided. 
TABLE IV(a)

ORIGINAL FY 1989 PLANNED EXPERIMENT TASK RUN DAYS

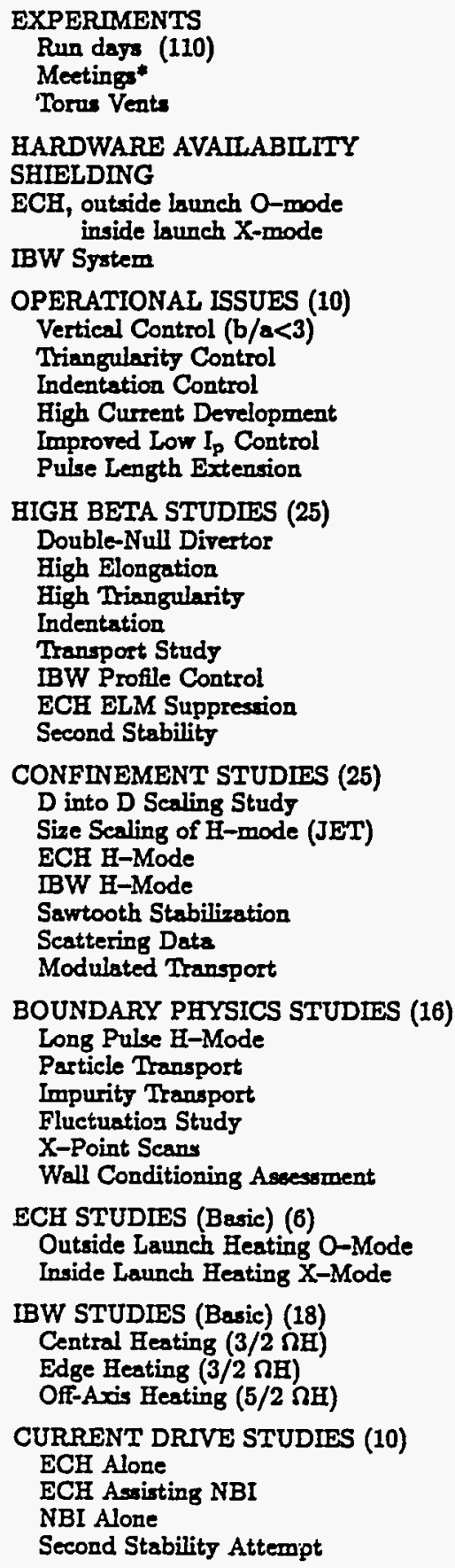

*Meetings: I = IAEA; A = APS.

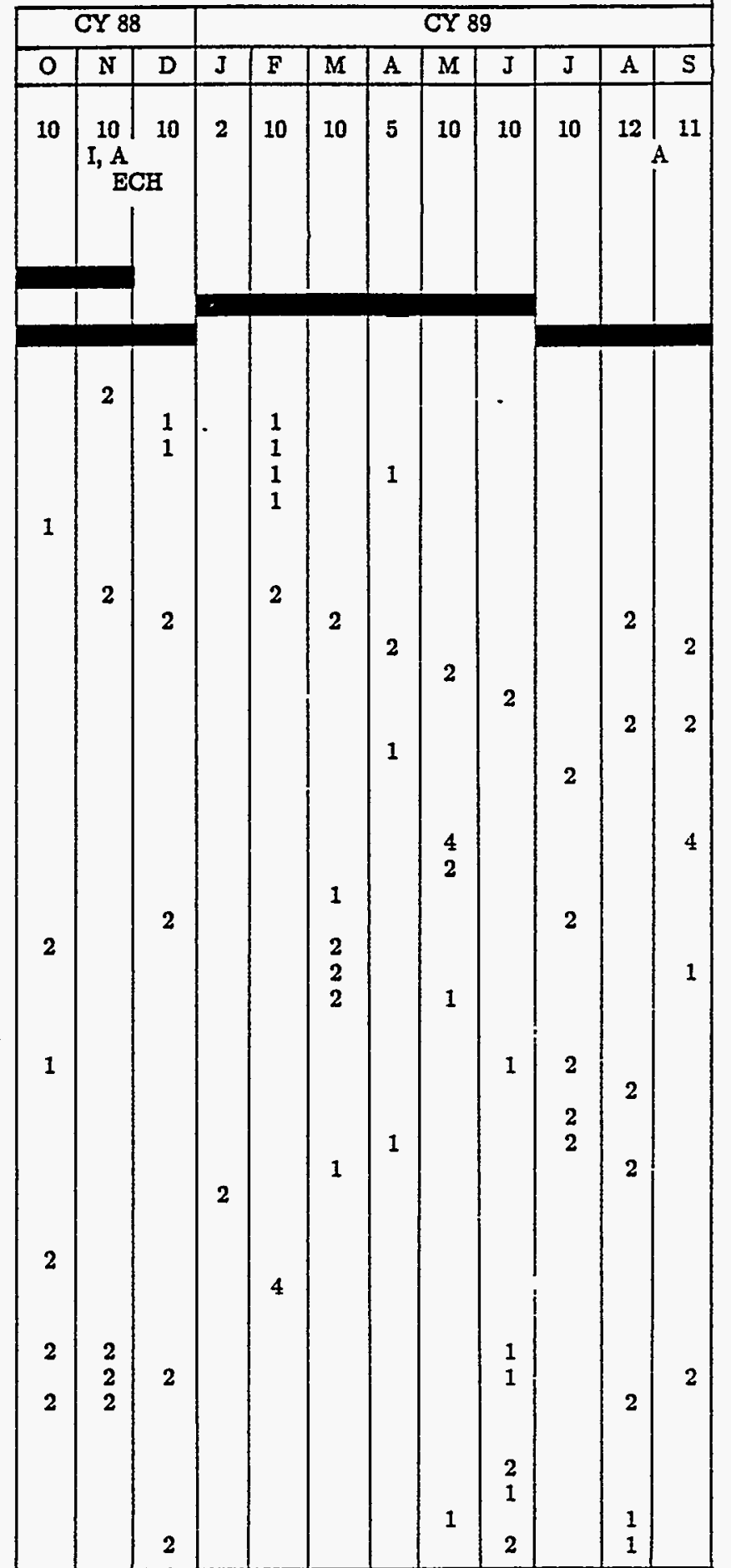


TABLE IV(b)

UPDATED FY 1989 DIII-D PLANNED EXPERIMENT TASK RUN DAYS

\begin{tabular}{|c|c|c|c|c|c|c|c|c|c|c|}
\hline $\begin{array}{c}\text { Experiments } \\
\text { Run Days } \\
\text { Meetings }\end{array}$ & $\begin{array}{c}\text { Mar } \\
5\end{array}$ & $\begin{array}{c}\text { Apr } \\
15\end{array}$ & $\begin{array}{c}\text { May } \\
12\end{array}$ & $\begin{array}{c}\text { Jun } \\
16\end{array}$ & $\begin{array}{c}\text { Jul } \\
6\end{array}$ & $\begin{array}{c}\text { Aug } \\
14\end{array}$ & $\begin{array}{c}\text { Sep } \\
16\end{array}$ & $\begin{array}{c}\text { Oct } \\
10\end{array}$ & $\begin{array}{c}\text { Nov } \\
7 \\
\text { APS }\end{array}$ & $\begin{array}{c}\text { Dec } \\
10\end{array}$ \\
\hline NEUTRAL BEAM POWER (MW) & 12 & & . & . & . & 16 & . & 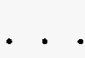 & . . & . . \\
\hline ECH POWER (MW) & & & 1.8 & & . . & . . & $\cdot \cdot$ & $\cdot$ & . . . & . . \\
\hline IBW POWER (MW) & 2 & & . & . & . . & . . . & . . & . . & . . . & . $\cdot$ \\
\hline NEUTRON SHIELDING FACTOR & 10 & 30 & 30 & 100 & & . $\cdot$ & . & . . & . . & $\cdot \cdot$ \\
\hline \multicolumn{11}{|l|}{ OPERATIONAL ISSUES } \\
\hline ECH preionization & & & & 1 & 1 & & & & & \\
\hline Locked mode studies & & & & 1 & & & & 1 & & \\
\hline Density limit studies & & 1 & 1 & & & & & & & \\
\hline High elongation development & & & & 2 & & 2 & & & & \\
\hline Pulsed discharge cleaning & 2 & & & & & & & & & \\
\hline Develop carbonization & & & & & & & & & 2 & \\
\hline Density control using glow & & 1 & 1 & & & & & & & \\
\hline Routine SND, 2.5 MA plasma & & & 2 & & & & & & & \\
\hline Develop 3.0 MA d-n divertor & & & & & & & & 1 & & \\
\hline High performance plasmas & & & & & 1 & & & 1 & & \\
\hline \multicolumn{11}{|l|}{ CONFINEMENT PHYSICS } \\
\hline Current, power and density scan & & & 1 & & & 2 & & 2 & & \\
\hline Size scaling with JET & & 2 & & & & & & & & \\
\hline Ohmic $\mathrm{H}$-mode & & & & & 1 & & & & & \\
\hline Super $\mathrm{H}$-mode development & & & & 2 & 1 & & 2 & & & 2 \\
\hline Low $q$ confinement studies & & & & & & 1 & & 2 & & \\
\hline L-mode density scan (Waltz) & & & & 1 & & 1 & & & & \\
\hline Vary ion heating profile (fluc.) & & & & 1 & & & & & & \\
\hline Isotope effect investigations & & & & 2 & & & & & & \\
\hline Modulated transport studies & & & & & & & 2 & & & \\
\hline Neoclassical comparison at high $I_{p}$ & & & 2 & & & & & & & \\
\hline $\mathrm{L}$-mode vs $\mathrm{H}$-mode $\chi$ comparison & & & & 1 & & & & & & \\
\hline Dependence on vertical elongation & & & & & & & & 1 & & \\
\hline \multicolumn{11}{|l|}{ Fast electron transport } \\
\hline Transport and fluctuation studies & & & & & & 2 & 2 & & & \\
\hline Counter-injection with D-beams & & & & & & & 2 & & & \\
\hline Error fields & & & & & & & & & & 1 \\
\hline Ion temperature gradient modes & & & & & & & & & & 1 \\
\hline Electron drift wave & & & & & & & & & & 2 \\
\hline
\end{tabular}


TABLE IV(b) (Continued)

\begin{tabular}{|c|c|c|c|c|c|c|c|c|c|c|}
\hline $\begin{array}{l}\text { Experiments } \\
\text { Run Days } \\
\text { Meetings }\end{array}$ & $\begin{array}{c}\text { Mar } \\
5\end{array}$ & $\begin{array}{l}\text { Apr } \\
15\end{array}$ & $\begin{array}{c}\text { May } \\
12\end{array}$ & $\begin{array}{c}\text { Jun } \\
16\end{array}$ & $\begin{array}{c}\text { Jul } \\
6\end{array}$ & $\begin{array}{c}\text { Aug } \\
14\end{array}$ & $\begin{array}{l}\text { Sep } \\
16\end{array}$ & $\begin{array}{l}\text { Oct } \\
10\end{array}$ & $\begin{array}{l}\text { Nov } \\
7 \\
\text { APS }\end{array}$ & $\begin{array}{c}\text { Dec } \\
10\end{array}$ \\
\hline \multicolumn{11}{|l|}{ BOUNDARY PHYSICS } \\
\hline \multicolumn{11}{|l|}{ Power and particle exhaust } \\
\hline \multicolumn{10}{|l|}{ X-point sweeping } & \\
\hline $\begin{array}{l}T_{e} \text { and } T_{i} \text { changes at } L \text { to } H \text { trans } \\
L \text { to } H \text { edge rotation change in } \\
\text { counterinjection }\end{array}$ & & & & & & & 2 & & & \\
\hline \multicolumn{11}{|l|}{ Low density limit of $\mathrm{H}$-mode } \\
\hline Fluctuation changes at $L$ to $H$ trans & & & & 2 & & 1 & & 2 & & \\
\hline $\begin{array}{l}\text { Limiter } \mathrm{H} \text {-mode } \\
\text { ELM stabilization studies }\end{array}$ & & 2 & & & & 1 & & 2 & & 2 \\
\hline \multicolumn{11}{|l|}{ Test of Hinton-Staebler theory } \\
\hline $\begin{array}{l}\mathrm{H} \text {-mode studies with } \mathrm{ECH} \\
\mathrm{H} \text {-mode with IBW } \\
\text { Advanced divertor tech. tests }\end{array}$ & & & & 2 & 1 & & 2 & & & \\
\hline \multicolumn{11}{|l|}{ HIGH BETA WORK } \\
\hline $\begin{array}{l}\text { Profile control and } n=4,3,2,1 \\
\text { modes }(E C H)\end{array}$ & & 2 & & & & & 1 & 2 & & \\
\hline Beta limits and sawteeth & & & 1 & & & & & & & \\
\hline Test Troyon vs shape and elongation & & & & & & & & 1 & & 2 \\
\hline $\begin{array}{l}\text { Beta limits at high temp. and field } \\
\text { Second stability experiments }\end{array}$ & & & 1 & 1 & & 2 & $\begin{array}{l}1 \\
2\end{array}$ & 1 & & \\
\hline $\mathrm{ECH}$ & & & & & & & & & & \\
\hline Fundamental heating studies & & & 3 & & & & & & & \\
\hline Sawtooth suppression & & & 1 & & & & & & 1 & \\
\hline High temperature with $\mathrm{NBI}$ & & & & & & 2 & & & 2 & \\
\hline \multicolumn{11}{|l|}{ IBW } \\
\hline $\begin{array}{l}\text { Search for IBW heating } \\
\text { Document IBW heating }\end{array}$ & & 2 & & 2 & & 2 & 1 & & 4 & \\
\hline \multicolumn{11}{|l|}{ CURRENT DRIVE } \\
\hline ECH current drive & & & 1 & & 1 & & & & & \\
\hline Alfvèn instability experiment & & 2 & & & & & 1 & & & \\
\hline NBI current drive & & & & & & & 1 & & & \\
\hline $\mathrm{ECH}$ enhanced $\mathrm{NBI}$ drive & & & & & & & 1 & 1 & & \\
\hline
\end{tabular}




\section{DETAIL HARDWARE PLAN}

This section contains the master schedule of all milestones currently agreed and the schedules for specific hardware tasks. Table $V$ is the master schedule used by General Atomics to monitor work on DIII-D.

Table $V(b)$ is the revised master schedule for the remainder of the calendar year. The run weeks shown for the remainder of FY89 reflect 26 weeks of operations. The weeks have been organized to reflect the timing of other external events such as the APS and Fusion Engineering Meeting. Extensive operation is planned for the remainder of the calendar year to provide the detailed studies outlined earlier in this document. 


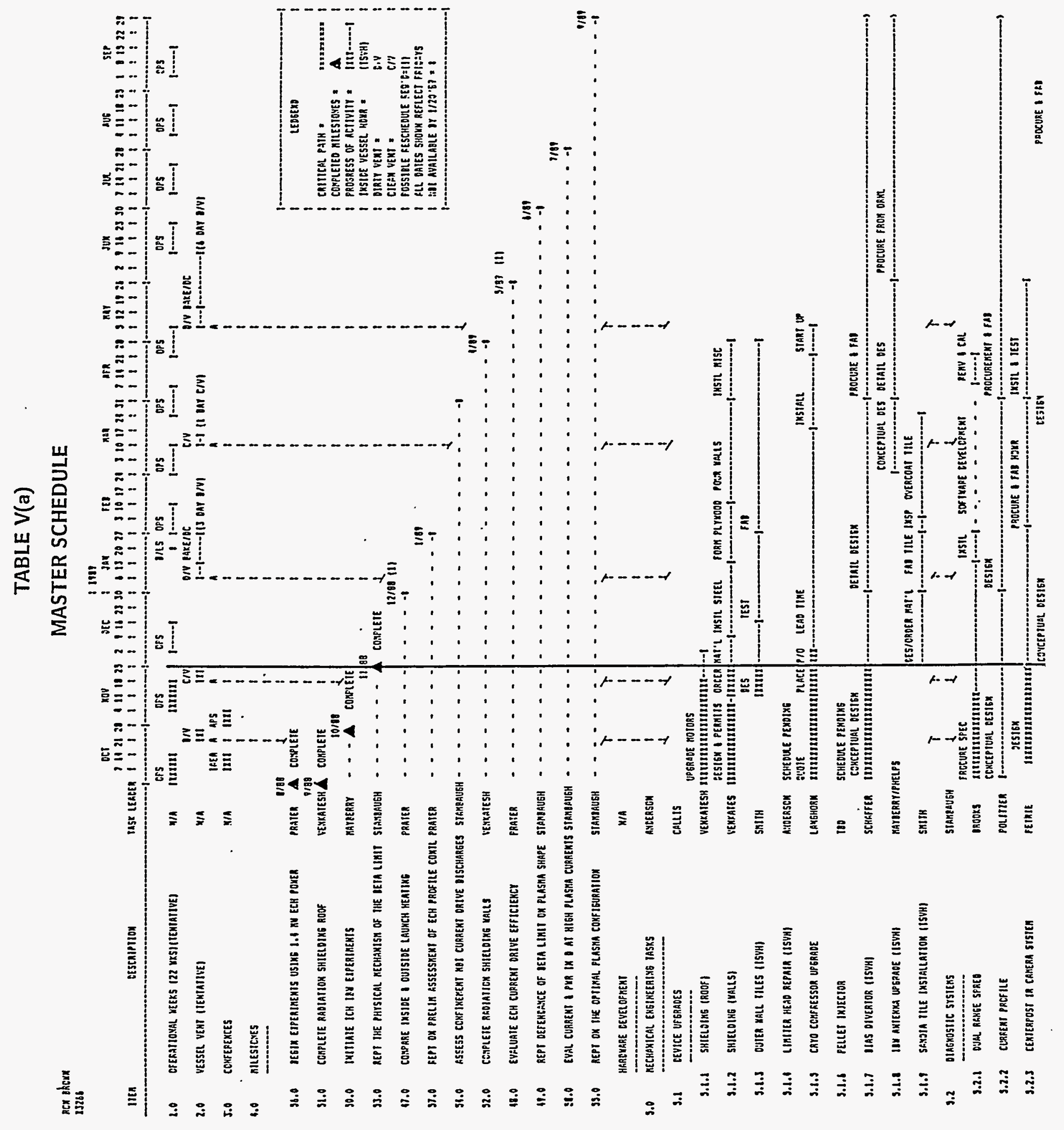




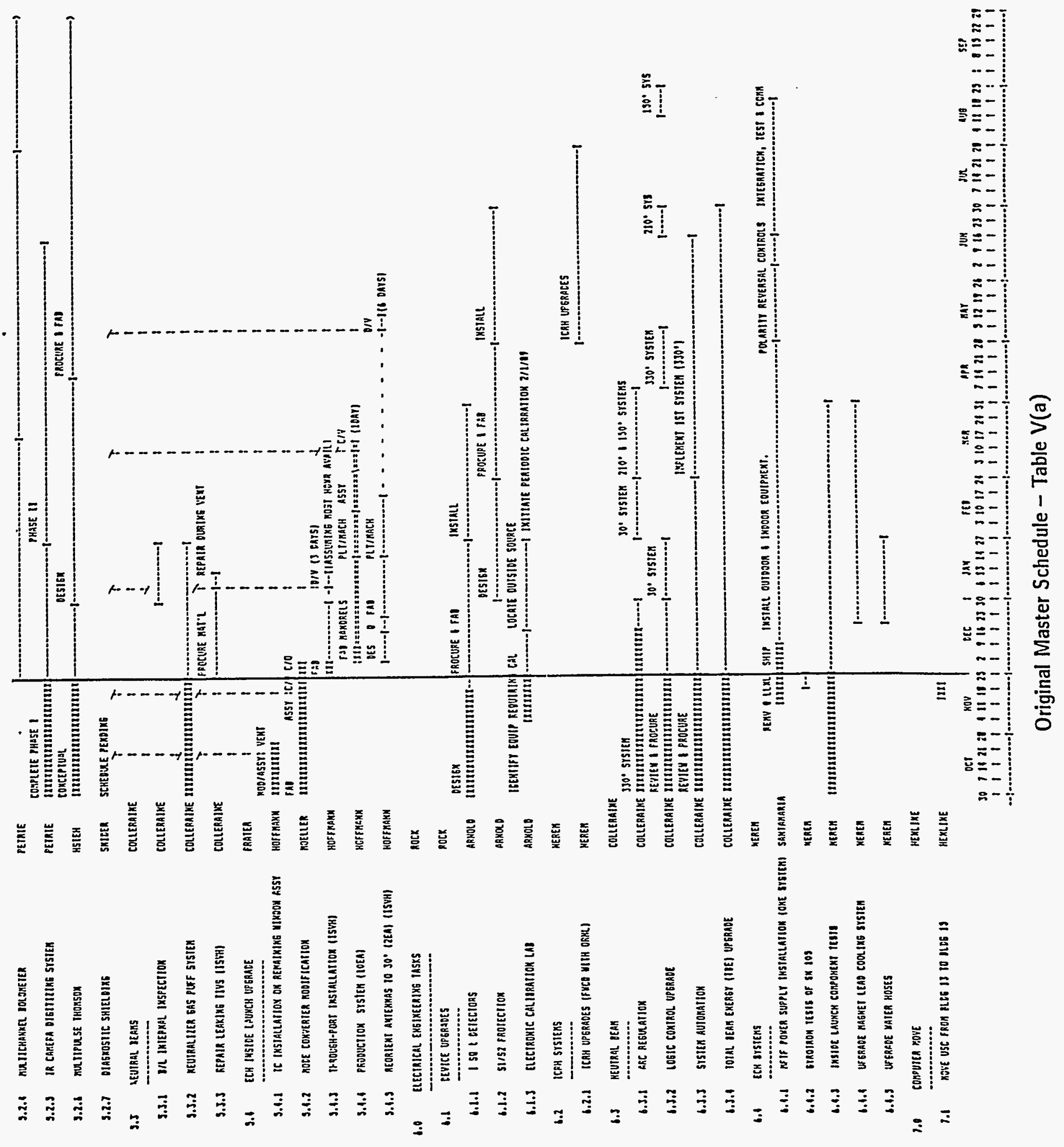




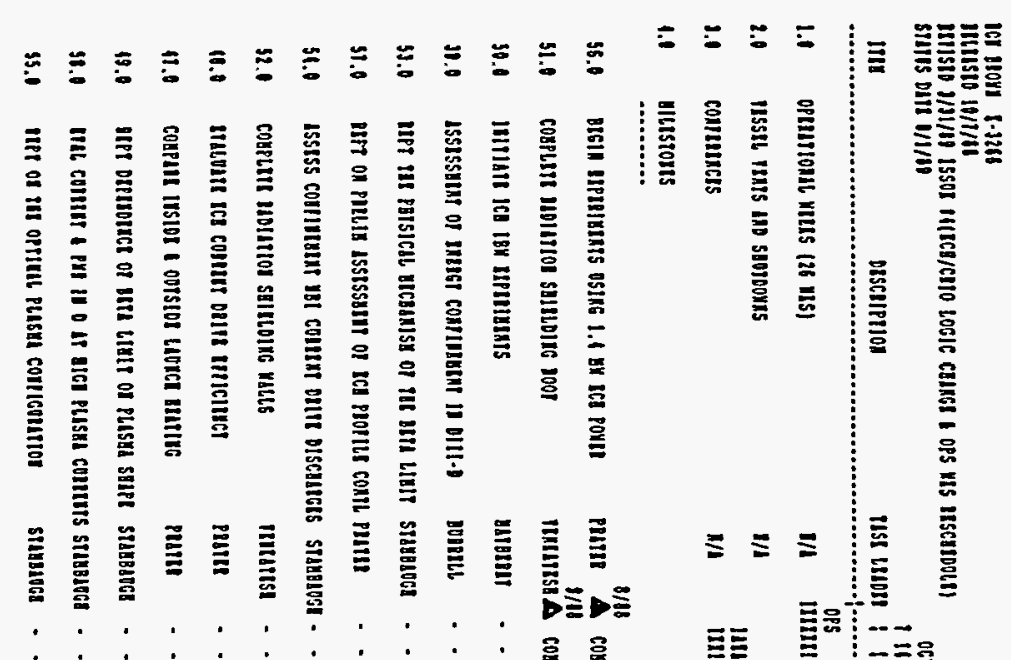

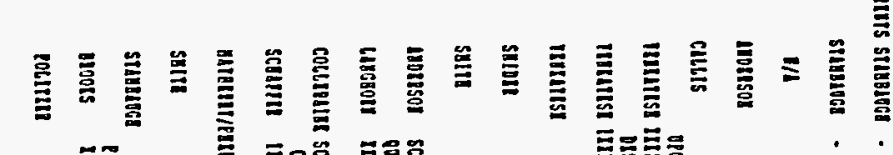

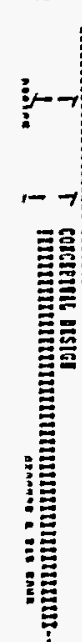




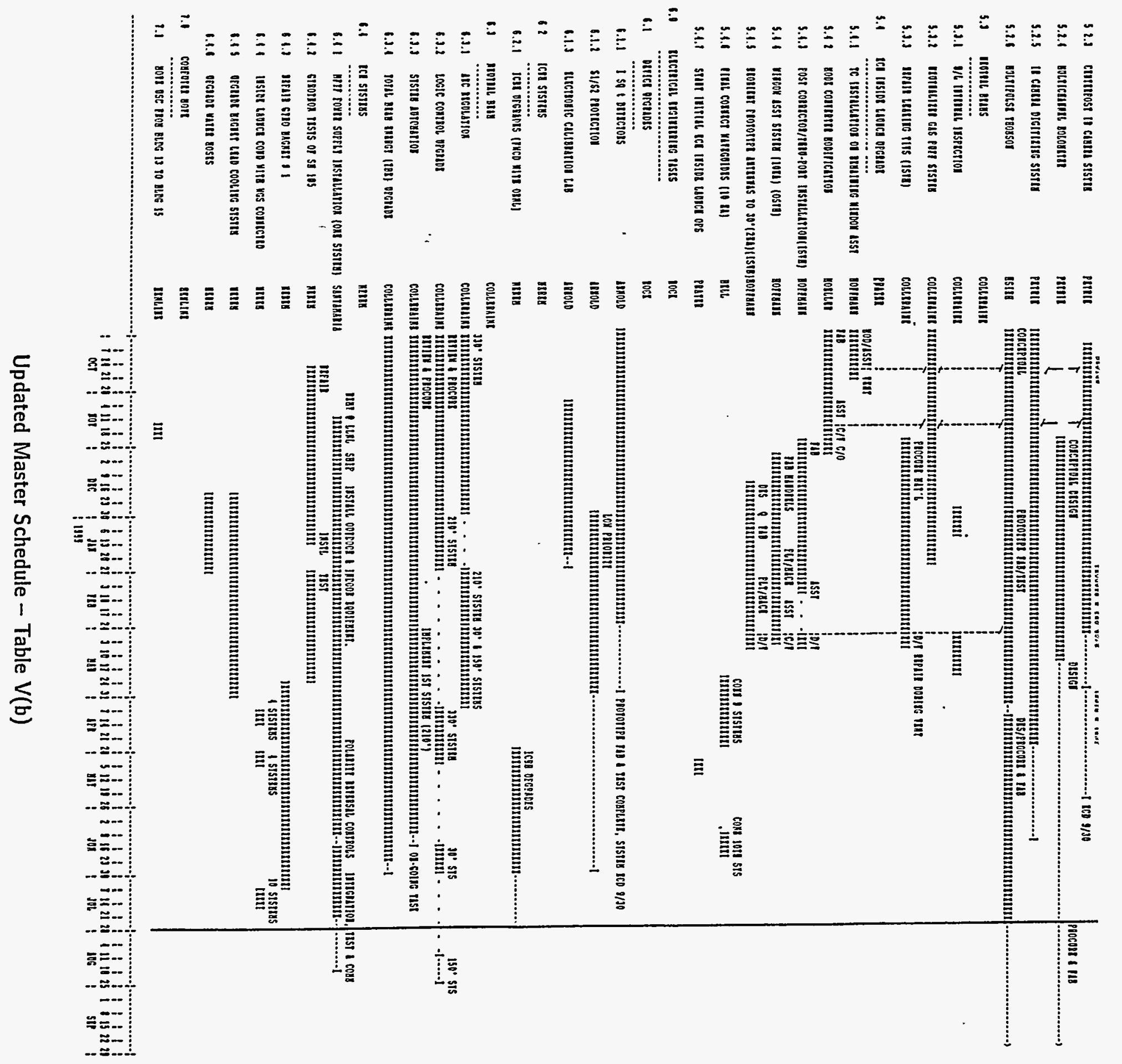




\section{MILESTONE SCHEDULE (Research Operations)}

\begin{tabular}{|c|c|c|c|}
\hline & Task Description & $\begin{array}{l}\text { Approved } \\
\text { (Target) } \\
\text { Date }\end{array}$ & $\begin{array}{l}\text { Completed } \\
\text { Date }\end{array}$ \\
\hline 37. & $\begin{array}{l}\text { Correlate beta results with previous } \\
\text { Doublet III results }\end{array}$ & $3-88$ & $3-88$ \\
\hline 38. & $\begin{array}{l}\text { Compare observed beta limits with first } \\
\text { stability regime theories }\end{array}$ & $3-88$ & $3-88$ \\
\hline 39. & Assessment of energy confinement in DIII-D & $11-88$ & $11-88$ \\
\hline 40. & $\begin{array}{l}\text { Report final assessment of outside } \\
\text { launch ECH heating }\end{array}$ & $9-87$ & $9-87$ \\
\hline 42. & Evaluate $\beta$ limit of a discharge with $I / a B>3$ & $6-88$ & $3-88$ \\
\hline 43. & $\begin{array}{l}\text { Evaluate } \beta \text { limit of a divertor discharge } \\
\text { with } I / a B>2.3\end{array}$ & $3-88$ & $3-88$ \\
\hline 44. & $\begin{array}{l}\text { Report comparison of modeling of divertor } \\
\text { neutral pressure with experimental results } \\
\text { (with PPPL or LLNL) }\end{array}$ & $12-87$ & $12-87$ \\
\hline 45. & Initiate inside launch ECH experiment & $3-88$ & $3-88$ \\
\hline 46. & Evaluate confinement in double null divertors & $7-88$ & $7-88$ \\
\hline 47. & Compare ECH inside and outside launch heating & $6-89$ & $6-89$ \\
\hline 48. & Evaluate ECH current drive (with LLNL) & $5-89$ & $6-89$ \\
\hline 49. & Evaluate $\beta$ limit of a double null divertor & $6-89$ & $6-89$ \\
\hline 50. & Initiate ICH IBW experiments & $10-88$ & $10-88$ \\
\hline 51. & Complete radiation shielding roof & $9-88$ & $10-88$ \\
\hline 52. & Complete radiation shielding walls & $4-89$ & $4-89$ \\
\hline 53. & $\begin{array}{l}\text { Report on the physical mechanism } \\
\text { of the } \beta \text { limit }\end{array}$ & $11-88$ & $10-88$ \\
\hline 54. & $\begin{array}{l}\text { Assess stability and confinement in } \\
\mathrm{NBI} \text { current driven discharges }\end{array}$ & $3-89$ & $3-89$ \\
\hline 55. & $\begin{array}{l}\text { Assess optimization of plasma } \\
\text { configuration for maximum } \beta \tau\end{array}$ & $9-89$ & \\
\hline 56. & $\begin{array}{l}\text { Begin experiments using } 1.4 \mathrm{MW} \\
\text { generated } \mathrm{ECH} \text { power }\end{array}$ & $8-88$ & $8-88$ \\
\hline 57. & $\begin{array}{l}\text { Report on a preliminary assessment } \\
\text { of ECH profile control }\end{array}$ & $1-89$ & $1-89$ \\
\hline
\end{tabular}




\begin{tabular}{|c|c|c|c|}
\hline & Task Description & $\begin{array}{l}\text { Approved } \\
\text { (Target) } \\
\text { Date }\end{array}$ & $\begin{array}{l}\text { Completed } \\
\text { Date }\end{array}$ \\
\hline 58. & $\begin{array}{l}\text { Extend current scaling, power scaling, } \\
\text { and isotope studies to } 2.5 \mathrm{MA} \text { and } \\
10 \mathrm{MW} D \rightarrow \mathrm{D}\end{array}$ & 7-89 & $7-89$ \\
\hline 59. & $\begin{array}{l}\text { Report results of Outside Launch ECH } \\
\text { Current Drive Experiments }\end{array}$ & $(12-90)$ & \\
\hline 60. & $\begin{array}{l}\text { Evaluate the potential of IBW heating } \\
\text { for tokamaks }\end{array}$ & 4-90 & \\
\hline 61. & $\begin{array}{l}\text { Evaluate the role of profile control } \\
\text { in modifying } \beta \text { limits }\end{array}$ & $7-90$ & \\
\hline 62. & $\begin{array}{l}\text { Complete interim report on DIII-D ITER } \\
\text { Physics R\&D }\end{array}$ & $(10 / 89)^{*}$ & \\
\hline 63. & $\begin{array}{l}\text { Submit initial report on fluctuation measurement } \\
\text { studies (with UCLA) }\end{array}$ & $(12 / 89)^{*}$ & \\
\hline 64. & Submit report on results of Local Transport Studies & $(3 / 90)^{*}$ & \\
\hline 65. & $\begin{array}{l}\text { Complete installation of Advanced Divertor } \\
\text { (with LLNL, ORNL, SNLA, SNLL, UCLA) }\end{array}$ & $(5 / 90)^{*}$ & \\
\hline 66. & $\begin{array}{l}\text { Complete installation of Fast Wave Current } \\
\text { Drive Antenna (with ORNL) }\end{array}$ & $(5 / 90)^{*}$ & \\
\hline 67. & $\begin{array}{l}\text { Complete interim report on DIII-D ITER } \\
\text { Physics R\&D }\end{array}$ & $(6 / 90)^{*}$ & \\
\hline 68. & Operate prototype $110 \mathrm{GHz}$ gyrotron at $\mathrm{GA}$ & $(7 / 90)^{*}$ & \\
\hline 69. & Evaluate the role of edge electric fields in $\mathrm{H}$-mode & $(8 / 90)^{*}$ & \\
\hline 70. & $\begin{array}{l}\text { Evaluate confinement in } \mathrm{H} \text {-mode with density profiles } \\
\text { modified with pellet injection }\end{array}$ & $(8 / 90)^{*}$ & \\
\hline 71. & $\begin{array}{l}\text { Complete interim report on DIII-D ITER } \\
\text { Physics R\&D }\end{array}$ & $(10 / 90)^{*}$ & \\
\hline 72. & $\begin{array}{l}\text { Obtain First Data from Multipulse } \\
\text { Thomson Scattering radial profile }\end{array}$ & $(10 / 90)^{*}$ & \\
\hline 73. & $\begin{array}{l}\text { Correlate turbulence measurements with ITG } \\
\text { mode theory }\end{array}$ & $(12 / 90)^{*}$ & \\
\hline 74. & Test particle control with the Advanced Divertor & $(12 / 90)^{*}$ & \\
\hline 75. & Evaluate Fast Wave Current Drive efficiency & $(3 / 91)^{*}$ & \\
\hline 76. & $\begin{array}{l}\text { Begin DIII-D } 110 \mathrm{GHz} \text { ECH experiments with } \\
4 \text { gyrotron system }\end{array}$ & $(6 / 91)^{*}$ & \\
\hline
\end{tabular}

*Proposed new milestones. 


\section{DIII-D CONFINEMENT UNDERSTANDING PROGRAM}

DIII-D has a carefully developed program to improve confinement understanding. The DIII-D tokamak is well suited for experiments directed at improving confinement understanding due to its ability to obtain enhanced confinement over a wide range of parameter space relevant to next generation devices such as CIT and ITER. Our confinement program is concentrating on $\mathrm{H}$-mode and edge physics where we have unique diagnostic and machine capabilities. The unique capabilities include:

- Significant plasma current (3.0 MA limiter, 2.5 MA divertor).

- Elongated plasma shape $(\kappa \leq 2.5)$ and double null divertor.

- Substantial neutral beam heating: $14 \mathrm{MW} \mathrm{H}^{\circ}, 16 \mathrm{MW} \mathrm{D}^{\circ}$.

- Localized of heating for modulated transport studies: $2 \mathrm{MW} \mathrm{ECH}$ and $\mathrm{ICH}$.

- H-mode operation (NBI, ECH, ohmic, limiter).

- High beta: $\beta_{\mathrm{T}} \leq 8 \%, \beta_{\mathrm{p}} \leq 4.5, \epsilon \beta_{\mathrm{p}} \leq 1.4$.

- Significant plasma parameters: $\bar{n}_{\mathrm{e}} \leq 1.4 \times 10^{20} \mathrm{~m}^{-3}, T_{\mathrm{i}} \leq 11 \mathrm{keV}, T_{\mathrm{e}} \leq 5 \mathrm{keV}$, $\tau_{\mathrm{E}} \leq 0.34$ sec.

- Mature profile diagnostic systems with edge profile resolution.

DIII-D experiments indicate that changes in edge plasma parameters, fluctuations, and radial electric fields are intimately connected with improved $\mathrm{H}$-mode confinement. The abrupt $\mathrm{L}-$ to $\mathrm{H}$-mode transition provides a unique opportunity for improving our understanding of $\mathrm{H}$-mode physics, determining the criteria required to achieve $\mathrm{H}$-mode, and predicting the subsequent confinement quality. 
We summarize here specific questions we will be addressing in the DIII-D confinement program and the new diagnostics and tools we will employ.

Relation to Theory. DIII-D confinement research will be guided by theoretical work on $\mathrm{L}-\mathrm{H}$-mode physics and edge plasma effects. In the next one to two years we intend to address specific theoretical questions, such as:

- What is the role of ITG and electron drift mode turbulence in the L-H transition? Theory predicts threshold ion temperature and density gradients, fluctuation spectral characteristics, and anomalous transport coefficients, all of which we will seek to measure.

- What is the mechanism of the L-H transition? Theories identify the edge electric field as important. We will concentrate on that hypothesis.

- Do magnetic perturbations that connect magnetic surfaces play a role? Possible sources of such perturbations are resistive modes or field errors. We will use superthermal electrons to probe the structure of such perturbations.

Several steps have been taken to enhance coordination between theory and experiment. These include increased emphasis and visibility through transport seminars, formation of several small working groups including non GA participants, and the development of theoretical-driven proposals for DIII-D transport experiments. Examples of present theoretical interactions are listed in Table VI. We are encouraging more interactions to develop to address specific questions arising from our experiments.

New Diagnostics. New diagnostics will be applied to DIII-D to improve our understanding of confinement. These include:

- Improved radial resolution of ion temperature and rotation profiles to compare measurements of gradients with theories based on the ion temperature gradient mode and on the effects of radial electric fields on $\mathrm{H}$-mode. 
Table VI. DIII-D TRANSPORT PHYSICS COLLABORATIONS

\begin{tabular}{|c|c|c|c|c|}
\hline & Program & Institutions & Participants ${ }^{\dagger}$ & Program Elements \\
\hline \multirow[t]{3}{*}{1.} & Edge Turbulence Studies & $\begin{array}{l}\text { UC San Diego } \\
\text { (Theory) }\end{array}$ & $\begin{array}{l}\text { Diamond } \\
\text { Biglari } \\
\text { Rosenbluth } \\
\text { Burrell GA }\end{array}$ & $\begin{array}{l}\text { - Characterize edge turbulence } \\
\text { - L- to H-mode transition } \\
\text { - Other outside collaborators }\end{array}$ \\
\hline & & $\begin{array}{l}\text { UC Los Angeles } \\
\text { (Diagnostics) }\end{array}$ & $\begin{array}{l}\text { Peebles } \\
\text { Luhman } \\
\text { Philipono } \\
\text { LeHecka* } \\
\text { Doyle }\end{array}$ & $\begin{array}{l}\text { - Reflectometry and FIR scattering } \\
\text { - Edge turbulence }\end{array}$ \\
\hline & & $\begin{array}{l}\text { Advanced Divertor } \\
\text { Program }\end{array}$ & $\begin{array}{l}\text { LLNL, ORNL, SNLL, } \\
\text { SNLA, UCLA }\end{array}$ & $\begin{array}{l}\text { - Edge currents, edge probes } \\
\text { - Divertor biasing and baffling }\end{array}$ \\
\hline \multirow[t]{3}{*}{2.} & H-mode Physics & $\begin{array}{l}\text { Princeton } \\
\text { (Theory/Data } \\
\text { Analysis) }\end{array}$ & $\begin{array}{l}\text { Tang } \\
\text { Hinton GA } \\
\text { Stockdale* GA } \\
\text { Waltz GA } \\
\text { Dominguez GA }\end{array}$ & $\begin{array}{l}\text { - Neoclassical transport modification } \\
\text { by anomalous transport } \\
\text { - Analysis of modulated ECH } \\
\text { - ITG mode with flat density profile }\end{array}$ \\
\hline & & $\begin{array}{l}\text { JAERI } \\
\text { (experimental) }\end{array}$ & Matsumoto & - H-mode experiments \\
\hline & & $\begin{array}{l}\text { Advanced Divertor } \\
\text { Program }\end{array}$ & $\begin{array}{l}\text { LLNL, ORNL, SNLL, } \\
\text { SNLA, UCLA }\end{array}$ & - Density control \\
\hline 3. & Low $q$ Confinement & $\begin{array}{l}\text { U Wisc. } \\
\text { (Theory/Data } \\
\text { Analysis) }\end{array}$ & $\begin{array}{l}\text { Callen } \\
\text { Cheng* } \\
\text { Schissel GA }\end{array}$ & $\begin{array}{l}\text { - UW has modified code for } \\
\text { noncircular tokamak } \\
\text { - Compare with DIII-D data }\end{array}$ \\
\hline 4. & $\begin{array}{l}\text { Transport in Elongated } \\
\text { Plasmas }\end{array}$ & $\begin{array}{l}\text { UC Berkeley } \\
\text { (Theory/Data } \\
\text { Analysis) } \\
\text { UCSD } \\
\text { MIT }\end{array}$ & $\begin{array}{l}\text { Fowler } \\
\text { Post Doc } \\
\text { Student* } \\
\text { Student* } \\
\frac{\text { Groebner }}{\text { Wolfe }}\end{array}$ & $\begin{array}{l}\text { - Students to help with } \\
\text { transport analysis }\end{array}$ \\
\hline \multirow[t]{2}{*}{5.} & Resistive MHD & $\begin{array}{l}\text { Princeton } \\
\text { (Modeling) }\end{array}$ & $\begin{array}{l}\text { Bateman } \\
\text { Chu GA }\end{array}$ & $\begin{array}{l}\text { - PPPL CISLAND Code calculates satu- } \\
\text { rated island widths for resistive modes } \\
\text { - DIII-D EFIT equilibrium data will be } \\
\text { used to evaluate transport }\end{array}$ \\
\hline & & $\begin{array}{l}\text { GA Theory } \\
\text { (Modeling) }\end{array}$ & Chan GA & $\begin{array}{l}\text { - Combines stability codes (GATO, } \\
\text { CART, MBC, ADJ) with transport code } \\
\text { (ONETWO) to model DIII-D data } \\
\text { (requires APP GA theory funding) }\end{array}$ \\
\hline 6. & $\begin{array}{l}\text { Enhanced Confinement } \\
\text { Study and Current } \\
\text { Profile Control }\end{array}$ & $\begin{array}{l}\text { GA Theory } \\
\text { U. Wisc. } \\
\text { (Theory) }\end{array}$ & $\begin{array}{l}\text { Chan GA } \\
\text { Tataronis }\end{array}$ & $\begin{array}{l}\text { - Stabilization of trapped electron mode } \\
\text { by current profile control, drift reversal } \\
\text { (requires APP GA theory funding) } \\
\text { - Test Alfvèn wave current drive in } \\
\text { Phaedrus }\end{array}$ \\
\hline 7. & Fast Ion Physics & $\begin{array}{l}\text { UC Irvine } \\
\text { (Diagnostic/Data } \\
\text { Analysis) }\end{array}$ & $\begin{array}{l}\text { Heidbrink } \\
\text { Student* }\end{array}$ & $\begin{array}{l}\text { - Energetic lon Physics with good } \\
\text { energy resolution charge } \\
\text { exchange analyzer }\end{array}$ \\
\hline
\end{tabular}

Participants located at GA are underlined; students have asterisk. 
- Multipulse multi-laser Thomson scattering for $\mathrm{L}-$ to $\mathrm{H}$-mode and edge localized mode radial profile studies as well as for time-dependent modulated $(\mathrm{ECH}$, gas puff, pellets) transport evaluation of off-diagonal transport coefficients.

- Fluctuation diagnostics aimed at measuring density fluctuation spectra. Poloidal wave lengths will be determined by microwave scattering and radial correlation lengths by microwave reflectometry.

The DIII-D transport diagnostic upgrade plan is shown in Fig. 1. Other innovative proposals are developing, including spectroscopic and laser-holographic imaging of density fluctuations.

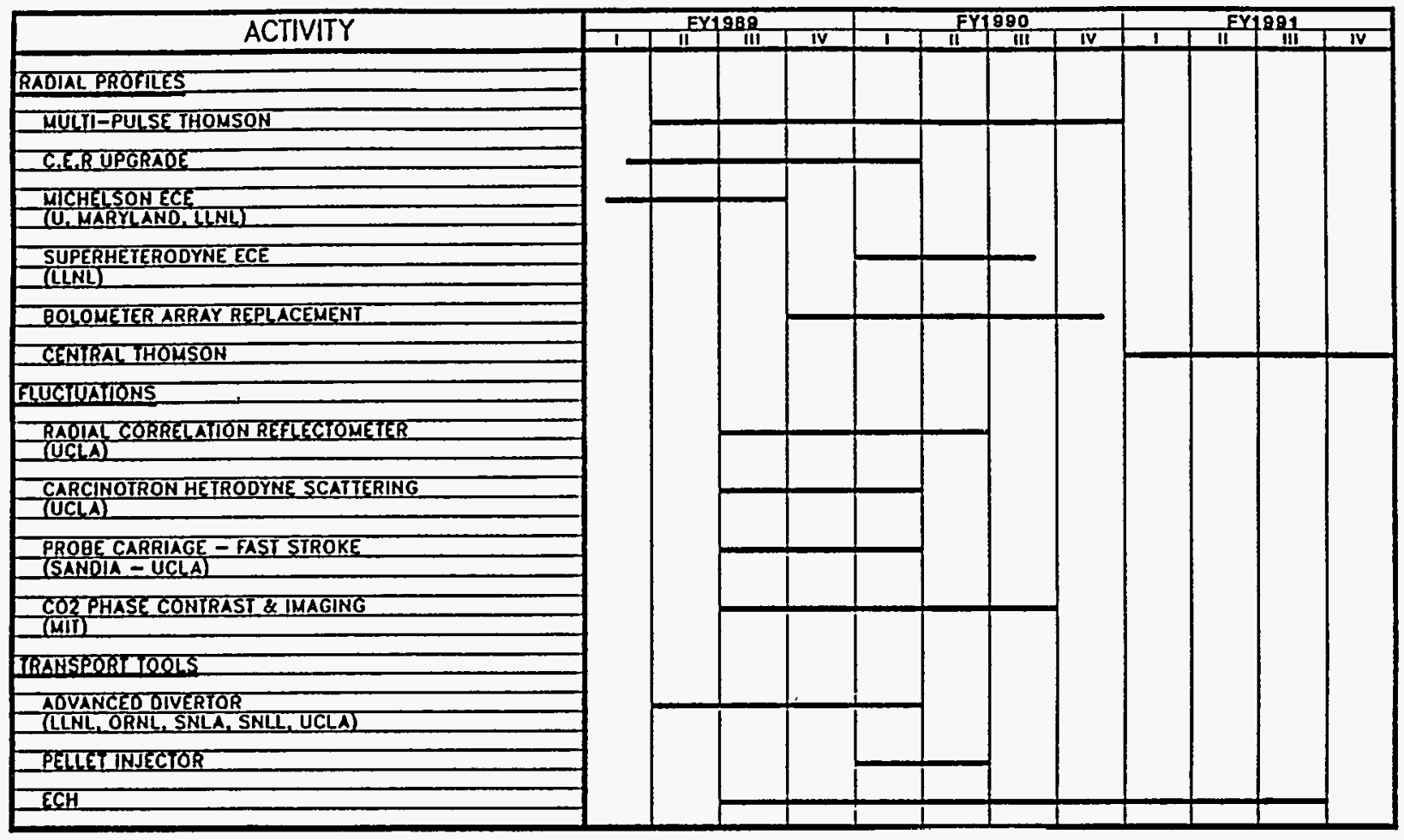

Fig. 1. DIII-D transport instrument and plasma transport control tools implementation plan diagnostic. Data will be available after the designated construction periods.

New Transport Tools. In addition to new transport diagnostics, three new control tools for confinement studies will be implemented on DIII-D. These are: 
- The Advanced Divertor should allow us to decouple the density and plasma current in $\mathrm{H}$-mode experiments. This tool will enable us to baffle, pump, bias, as well as to measure the predicted edge current flows.

- A pellet injector will allow us to control the radial density profile for ITG mode studies, conduct modulated particle transport experiments, and explore super $\mathrm{H}$-mode operation.

- The addition of $2 \mathrm{MW} 110 \mathrm{GHz}$ ECH will allow us to extend ECH H-mode studies to higher densities, explore the importance of profile control and to carry out both steady state and modulated transport studies at higher electron temperature. 


\section{DIII-D PROGRAM TO SUPPORT ITER AND CIT}

ITER

DIII-D is in a position to provide answers to a multitude of ITER design issues. Detailed responses were developed to the request for responses to the 24 ITER R\&D Physics Tasks. The tasks are summarized in Table VII, including the DIII-D responsible task leader and collaborators from outside the DIII-D program. The responses include objectives and detailed schedules for the period from now through September of 1990. These responses were reported (J. Luxon) to ITER during a meeting in Garching March 15, 1989 where the responses of the worldwide tokamak community were summarized. The response of the community was outstanding and the inputs are summarized in Table VIII. As indicated by the bold column DIII-D is expected to make the broadest contribution worldwide to ITER.

Recent DIII-D contribution to the ITER understanding base in the areas of confinement, high beta, and long pulse discharges have been particularly well received. DIII-D is viewed as a particularly valuable future contributor especially because of focus on $\mathrm{H}$-mode confinement, boundary physics, long pulse discharges and current drive.

Meeting these future commitments to ITER is going to take substantial effort, resources and dedication from the DIII-D team. 
TABLE VI

SUMMARY OF DIII-D CONTRIBUTIONS TO ITER

\begin{tabular}{|c|c|c|c|c|}
\hline Topic & & Unique & Investigator & Collaborators \\
\hline \multicolumn{5}{|l|}{ DESIGN RELATED } \\
\hline 1. Power and helium exhaust & A & DIV H-mode & Hill & LLNL, SNL \\
\hline 2. Helium radial distribution & B & DIV H-mode & Miley & U. Illinois \\
\hline 3. Radiative edge & B & DIV H-mode & Mahdavi & LLNL \\
\hline 4. Divertor sweeping & B & DIV & Hill & LLNL \\
\hline 5. Low-Z PFC materials & A & DIV & Hill & LLNL, SNL \\
\hline 6. High-Z PFC materials & & & & \\
\hline 7. Characterization of disruptions & B & Elongation & Taylor & PPPL \\
\hline 8. Disruption control & B & & Taylor & \\
\hline 9. RF plasma formation and preheating & B & $\mathrm{ECH}$ & Prater & Culham \\
\hline 10. RF current initiation & D & $\mathrm{ECH}$ & Prater & \\
\hline 11. Inductive volt-second consumption & B & & Taylor/Hogan & ORNL \\
\hline 12. Alpha-particle ripple losses & & & & \\
\hline 13. Plasma diagnostics & & & & \\
\hline \multicolumn{5}{|l|}{ PERFORMANCE-RELATED } \\
\hline 14. Steady-state enhanced confinement & A & $H$-mode, $D_{2}$ & Gohil & ASDEX \\
\hline 15. Tests of theoretical transport models & A & DIV & Burrell & JET \\
\hline 16. Control of MHD activity & B & & Strait & \\
\hline 17. Density limit & B & DIV & Petrie & \\
\hline 18. Plasma performance at high kappa & A & $\kappa$, double null & Lazarus & ORNL, Lusanne \\
\hline 19. Alpha particle simulations & B & & Heidbrink & U.C. Irvine \\
\hline 20. Electron cyclotron current drive & D & ECH power & Politzer & LLNL \\
\hline 21. Ion Cyclotron current drive & D & $\mathrm{ICH}$ power & Politzer & ORNL \\
\hline 22. Alfven wave instability & B & & Heidbrink & U.C. Irvine \\
\hline 23. Advanced fueling techniques & & & & \\
\hline 24. Aspect ratio scaling & & & & - \\
\hline
\end{tabular}

$A=$ strong contribution; $B=$ contribution; $D=$ primary contribution delayed until after 1990 by hardware availability. 
TABLE VII

\section{SUMMARY OF CONTRIBUTIONS TO ITER FROM FACILITIES WORLDWIDE}

The DIII-D contribution is enclosed in a heavy box.

\begin{tabular}{|c|c|c|c|c|c|c|c|c|c|}
\hline \multicolumn{3}{|c|}{$\begin{array}{c}\text { ITER PHYSICS R \& D PROGRAMME } \\
\text { (up to 1990) }\end{array}$} & \multicolumn{5}{|c|}{ CONTRIBUTIONS OFFERED } & \multicolumn{2}{|c|}{08 MAR 89} \\
\hline \multicolumn{3}{|c|}{ PARTNER } & \multicolumn{2}{|c|}{ EC } & J & su & \multicolumn{2}{|c|}{ USA } & \\
\hline \multicolumn{3}{|c|}{ DEVICE } & A $\quad$ B $C$ C D E & 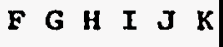 & L $\quad M \quad N \quad$ o & $\mathbf{p}$ & $\mathbf{Q} \mathbf{R}$ & T U V.W & \\
\hline \multicolumn{3}{|c|}{$\begin{array}{l}\text { DESIGN-RELATED } \\
01 \text { POwer and He exhaust } \\
02 \text { He radial distribution } \\
03 \text { Radiative edge } \\
04 \text { Divertor sweeping } \\
05 \text { LOw-z PFC materials } \\
06 \text { High-z PFC materials } \\
07 \text { Characterization of disruptions } \\
08 \text { Disruption control- } \\
09 \text { RF plasma formation/preheating } \\
10 \text { RF current initiation- } \\
11 \text { Inductive volt-second consumption } \\
11 \text { A R current ramp-up assist-- } \\
12 \text { Alpha particle ripple losses- } \\
13 \text { Plasma diagnostics-- }\end{array}$} & 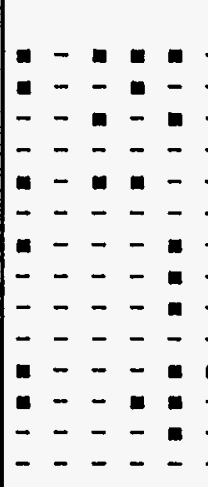 & 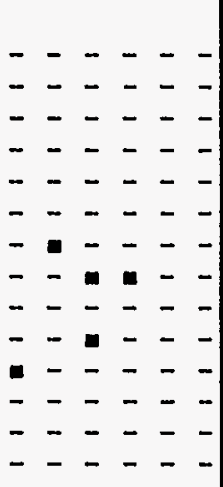 & 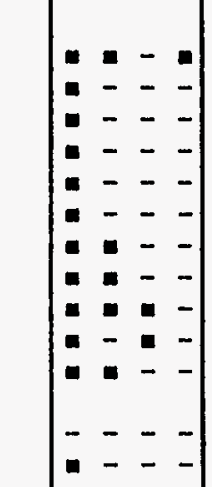 & $\begin{array}{l}\overline{-} \\
\overline{-} \\
- \\
\overline{-} \\
- \\
-\end{array}$ & 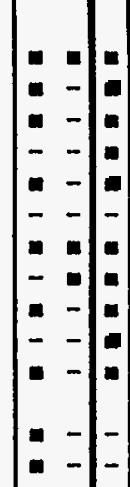 & $\begin{array}{llll}- & - & ? & - \\
- & - & - & - \\
- & - & - & - \\
- & - & - & - \\
- & - & - & - \\
- & - & - & - \\
1 & - & - & - \\
0 & - & - & - \\
- & - & - & - \\
- & - & - & - \\
- & - & - & - \\
- & - & - & - \\
- & - & - & -\end{array}$ & $\begin{array}{l}01 \\
02 \\
03 \\
04 \\
05 \\
06 \\
07 \\
08 \\
09 \\
10 \\
11 \\
11 A \\
12 \\
13\end{array}$ \\
\hline \multicolumn{3}{|c|}{$\begin{array}{l}\text { PERFORMANCE-RELATED } \\
14 \text { Steady-state enhanced confinement } \\
15 \text { Test theoretical transport models } \\
16 \text { Control of MHD activity- } \\
17 \text { Density limit-mance at high kappa- } \\
18 \text { Plasma performance } \\
19 \text { Alpha-particle simulations- } \\
20 \text { Electron cyclotron current drive- } \\
21 \text { Ion cyclotron current drive- } \\
22 \text { Alfvén wave instability-a } \\
23 \text { Advanced fuelling techniques---- } \\
24 \text { Scaling of plasma performance---- }\end{array}$} & 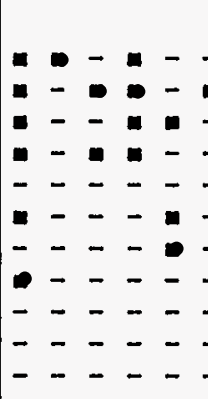 & 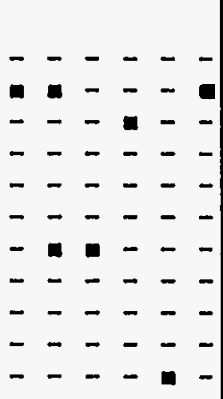 & 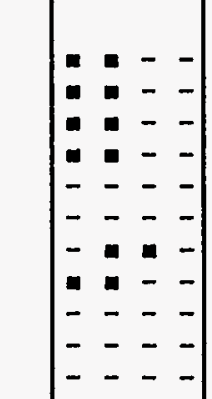 & $\begin{array}{l}- \\
- \\
- \\
- \\
- \\
- \\
- \\
-\end{array}$ & 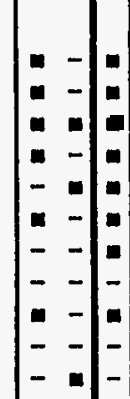 & $\left|\begin{array}{llll}- & - & - & - \\
- & - & - & 0 \\
0 & - & - & - \\
- & 0 & - & - \\
- & - & - & - \\
- & - & - & - \\
0 & - & - & - \\
- & - & - & - \\
- & - & - & - \\
0 & - & ? & - \\
- & - & - & -\end{array}\right|$ & $\begin{array}{l}14 \\
15 \\
16 \\
17 \\
18 \\
19 \\
20 \\
21 \\
22 \\
23 \\
24\end{array}$ \\
\hline \multicolumn{3}{|c|}{\begin{tabular}{l|lr|lr} 
LEGEND & A:JET & JET & F: FTU & ENEA \\
B:TEXTOR & ERM & G:RTP & FOM \\
C:TEXTOR & KFA & H:DITE & UKAEA \\
& D:ASDEX & IPP & I:COMPASS & UKAEA \\
E:TORE-SUPCEA & J:START & UKAEA
\end{tabular}} & \begin{tabular}{l|l}
$K:$ \\
$L: J T-60 M$ \\
$M: J E T-2 M$ \\
$N: W T-3$ \\
$O:$
\end{tabular} & $\begin{array}{r}\text { NFR } \\
\text { JAERI } \\
\text { JAERI. } \\
\text { Kyoto U. } \\
\text { Nagoya U. }\end{array}$ & $\begin{array}{l}\text { P:T-10 Ku } \\
\text { Q:TFTR Pr } \\
\text { R:PBX Pr } \\
\text { S:DIIID } \\
\text { T:MTX }\end{array}$ & $\begin{array}{l}\operatorname{tov} I . \\
\operatorname{ton} \mathrm{U} . \\
\text { ton } \mathrm{U} . \\
\text { GA } \\
\text { LLNL }\end{array}$ & \multicolumn{3}{|c|}{$\begin{array}{l}\text { U:ATE } \\
\text { V:TEXT, APP Texas U. } \\
\text { W:TTE Transport } \\
\\
\text { task force. }\end{array}$} \\
\hline
\end{tabular}




\section{$\mathrm{CIT}$}

Due to its size, shape and flexibility, DIII-D can resolve key issues associated with the design of CIT and thereby make significant and favorable budget and schedule impacts. Two specific areas have been recently identified where DIII-D research results contribute to the CIT design effort. These are low voltage plasma initiation, and divertor plate erosion studies. Plans are being laid to meet these needs with existing data and additional experiments. The need for rf-assisted breakdown data as part of the low voltage plasma initiation studies can be satisfied as part of the joint ECH experiments with Culham this summer. The erosion studies can be integrated into the ongoing studies with Sandia, LLNL, and others. 


\section{APPENDIX}

\section{TECHNICAL DIRECTION TO INCREASE TRANSPORT EMPHASIS}


U.S. DEPARTMENT OF ENERGY --

SAN FRANCISCO OPERATIONS OFFICE

Energy Research Division - San Diego Sitz Office

P.0. Box 85608, San Diego; California 93158

June 15,1989

Dr. T. Sinonen, DIII-D Program Director

Fusion Division

General Atonics Inc.

P.0. Box 85608

San Diego, CA 92138

Subj: Technical Direction for Contract DE-ACO3-B9ER51114.

Ref: (1) Meno from J.Wildis to N.A.Davies dtd 3/9/89, Subj: Progran Highlights - Response to the Transport Initiative - $3 / 3 / 89$.

Dear Ton,

Increaental funding in the amount of $\$ 3,000,000$ is being added to the subject contract in B\&R ATI01014D. The purpose of this action is to enhance the utilization of DIII-D in response to the Transport Initiative (Ref (1)). Guidance for costing these funds during Fy 1989 is as follows:

$$
\begin{aligned}
& \$ 1,400,000 \text { - for diagnostic iaprovements and enhanceaents. } \\
& \text { 1,000,000 - for increased experinental time. } \\
& \text { 400,000 - to inplenent the Advaneed Divertor Progran (ADP). } \\
& 200,000 \text { - to begin the inpleaentation of a pellet injector } \\
& \text { for DIII-D. }
\end{aligned}
$$

The DIII-D Experimental Plan is to be updated to reflect the enhanced efforts. Also, you are requested to propose a revised set of DIII-D project ailestones which reflect the shift in progras eaphasis toward transport studies. This aaterial should be prepared in tine for distribution at the next SAN quarterly review in July, 1989.

CEs Erol Oxtay, ER-5s

Aundra Richards, SAN-CM

Marilyn Saith, SAN-ER

JaERs Shakiba, SAN-ER
Very truly yours,

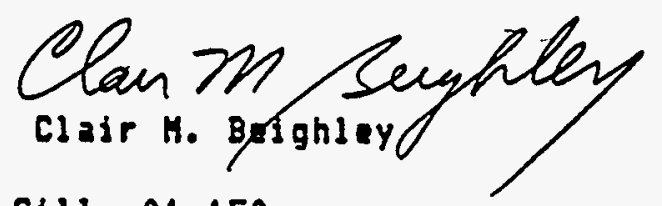

bei Don 6i11, 01-150

Jia Luxon, 13-25B

Keith Shoolbred, 13-206A 